\title{
4 \\ The State, the Land, and the Hill Museum
}

\author{
Hanan Toukan
}

How are we to think about a museum that represents a people who not only do not exist on conventional maps but who are also in the process of resisting obliteration by one of the most brutal military complexes in the world? What is, and what can be, the role of a museum in a violent colonial context compounded by the twin effects of imperialism and capitalism? Whom does the museum speak for in such a context? And what can or should it say to a transterritorial nation while physically located in a supposed state-to-be that has no real prospect of gaining control over its land, water, or skies through current international diplomatic channels?

Four interrelated phenomena are central to thinking through these questions in relation to the Palestinian Museum, which opened in 2016 in the university town of Birzeit in the West Bank, on a hill that offers a breathtaking view of farms, terraced hillsides, and the Mediterranean Sea. First, one must acknowledge the convoluted, bureaucratic, and deceptive nature of the Oslo peace process and the new phase of colonization that it inaugurated in 1993. This predicament, which has been described as one of living in a "postcolonial colony," is largely defined by the paradox of living in a state without sovereignty in the West Bank and Gaza under the guise of a diplomatic process leading toward a two-state solution. ${ }^{1}$ Under this regime, the Palestinian National Authority (PNA), established in 1994 as an outcome of the now unpopular Oslo Peace Accords, did not gain full sovereignty for itself or the Palestinian people it purportedly represents. Rather, it became the middleman of the Israeli occupation, managing security and repressing Palestinian dissent on behalf of Israel through its own internal military and intelligence apparatus, helping to intensify the Israeli colonial strategies of spatial segregation and economic control. At the same time, despite its increasing 
unpopularity, the PNA has continued to act as the recognized representative of a state-to-be in international diplomacy. This role has necessitated its cultural diplomacy and top-down identity formation in an attempt to rebrand Palestinians as nonviolent and modern global citizens residing within the 1967 bordersprocesses that are key to understanding how and why the Palestinian Museum has, from its inception, had to think about representing the story of the Palestinian people outside the limits of the diplomatically sanctioned, yet now probably defunct, two-state solution.

Second, one must take account of ongoing Israeli colonial practices of cultural exclusion and military domination. Supported by an architecture of bureaucratic hurdles and procedures, the Israeli occupation uses a carefully designed system of legalized, institutionalized, and normalized racial discrimination to debilitate the freedom of movement of objects, people, and ideas that a museum or any institution of knowledge production requires in order to function. As I demonstrate, the Palestinian Museum has had to maneuver around this in order to materialize.

Third, the Palestinian Museum has indirectly interrogated the European museum's Western-centric yet universalizing mission of acquiring, conserving, and displaying aesthetic objects as part of the project of constructing nation-states and indeed modernity itself. It is precisely because of the Palestinian Museum's restricted spatial reality that it is able to intervene in a global discussion concerned with the role of the museum in our world. This conversation centers on the question of how to make the museum-an institution historically bound up with the emergence of the nation-state and the notion of the public in eighteenth-century Europe-relevant to the global realities that shape its direction today. ${ }^{2}$ The Palestinian Museum can be read as proposing answers to this question, first through its mission of being "a museum without borders," and second through its very process of construction, which drew on the land's historically terraced landscapes to create a structure embedded in the communities and histories it seeks to speak to and for. ${ }^{3}$ Through this process, it arguably rethinks the "postcolonial museum" as an unstable yet dynamic memory-making institution, as much a living archive of violence as an affective encounter with the weight of the land and history. ${ }^{4}$ In doing so, it intervenes in a global conversation about the sensorial dimensions of exhibition and collection practices in violent settings on the margins of the global South.

The final aspect that informs my reading of the Palestinian Museum is the wave of state-supported building and renovation of museums and other art institutions underway largely in the Arab Gulf states but also in Lebanon, Egypt, Kuwait, and to a lesser extent Jordan, from which the Palestinian Museum is arguably set apart by virtue of its status as an institution representing a transterritorial and stateless nation. Unlike the regional museum projects surrounding it, which offer clear instances of top-down globally attuned national identity formation, stateled societal development, and soft power and public diplomacy, the Palestinian 


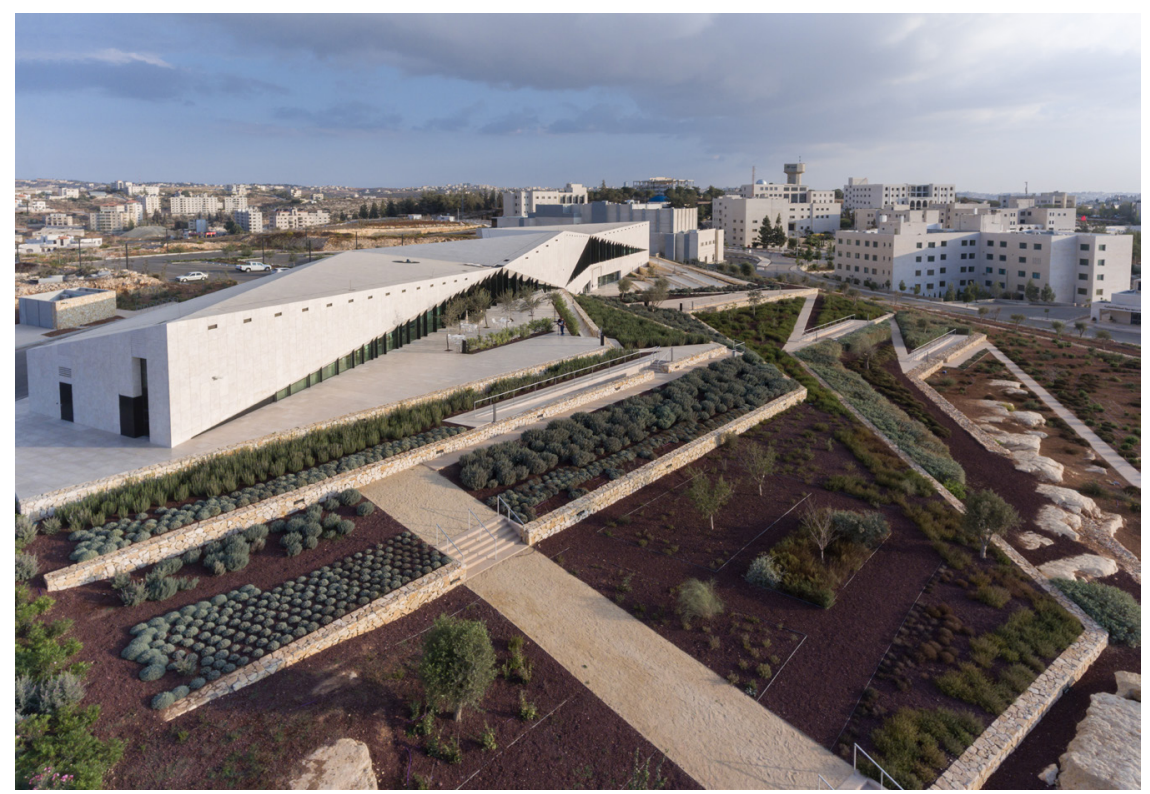

FIgure 2. The Palestine Museum. Source: Iwan Baan, (c) the Palestinian Museum.

Museum prompts a rethinking and reworking of the vexed relationship between local Palestinian noncitizens and transterritorial Palestinian publics and their supporters, on the one hand, and the aesthetic form of an exhibition and the tastes of its varied global audiences, on the other. ${ }^{5}$

On the surface, it is easy to dismiss the beautifully landscaped, bunker-like, low and uneven twenty-four million dollar building that has become known as the Palestinian Museum as the vanity project of one organization and possibly even one person. The Welfare Association, better known by its Arabic name, Taawon, meaning cooperation, is Palestine's largest humanitarian and development nongovernmental organization, founded in 1983 by a group of Palestinian business and intellectual figures. It has spearheaded the project in its various iterations since its inception in 1997. Headed by Omar Al-Qattan, former chairman and acting director of the Palestinian Museum project, board member of Taawon, chairman of the Al-Qattan Foundation, and son of one of Palestine and the Arab world's most beloved businessmen and philanthropists, the late Abdel Mohsen Al Qattan, Taawon played a highly visible role in the making of the museum. ${ }^{6}$ Taawon, which is highly respected regionally and locally in Palestine for its financial independence, especially from Western funders, and for its humanitarian work, is well known for how seriously it takes its self-proclaimed mission to "preserve the heritage of the Palestinians, supporting their living culture and building civil society." The museum, one of Taawon's flagship projects, became a crucial site 
for the implementation of its heritage mandate. As with most of its humanitarian projects, Taawon relied heavily on private money donated by Palestinian business entities on the association's board, such as Arab Tech Jardaneh (a private practice of consulting engineers), Consolidated Contractors Company (one of the earliest Arab construction companies), Al-Hani Construction and Trading (based in Kuwait), Projacs International (the largest Pan-Arab project management firm), as well as the Bank of Palestine.

Yet as is always the case with the building of art institutions with private sector funds, questions concerning transnational financial ties, corporate ethics, and relationships with local cultural elites arise. The role of Taawon prompted those working closely with the project and others observing from afar to ponder how much the project was about global capitalist elite collusion with the local NGO sector rather than response to the needs of the Palestinian people. In this regard, people I interviewed or conversed with as part of my research raised a number of provocative questions: first, about the manner in which Taawon disbursed funds earmarked for the cultural sector to one museum as opposed to a wider range of cultural projects, arts organizations, and other activist initiatives already underway in Palestine; second, about how Taawon was seen to run the museum as if it were one of its mainstream NGO socioeconomic development projects, without the curatorial insight needed to get a museum of this kind off the ground; third, about how, in the eyes of some, especially those not working directly within the museum or in the art world, the opening of an empty museum in May 2016 made clear just how much it had been compromised by mismanagement; and finally, and perhaps most ominously, about what to make of the allegation that Taawon board members were getting returns on their in-kind donations to the museum in a context that has allowed big businesses to set the terms of cooperation for smaller and more local businesses.

Sentiments like these gathered from discussions about the Palestinian Museum are a reminder that even the most brilliantly conceived projects encounter friction when they leave the space of conception to become transformed into concrete projects. Specifically, how museums located at the nexus of the colonial/postcolonial divide reinvent their spaces and visual narrations, in contexts in which the divisions between public and private are opaque, and access to landscapes and architectures necessary for the movement of objects restricted, is fundamentally a question of the political economy of cultural production. Though the Palestinian Museum has been able to propose innovative museum practices, its ability to survive its near-impossible predicament of belonging to a "state" that is not in a position to defend itself will ultimately depend on the extent to which the transnational networks, including the financial ones, that it draws upon will allow it to experiment freely with different forms of knowledge production, narrations of memory, and cultural heritage preservation. 


\section{AN EMPTY MUSEUM?}

If there is a blotch on the Palestinian Museum's image that metaphorically and visually represented some of the misgivings expressed about it, it was at its official opening on May 18, 2016, when there were no art objects in the building on display. The opening took place soon after the firing of Jack Persekian, the museum's chief curator and director since 2008, and one of the Arab region's most recognized contemporary arts curators, over "planning and management issues."

The museum was supposed to have opened with Persekian's curated project "Never Part," which was to have featured illustrative material objects from the lives of Palestinian refugees all over the world. The "Never Part" team envisioned and worked towards an empty museum for the opening, but they wanted interventions from artists contemplating the emptiness of the building vis-à-vis Palestine's experience of having had its material culture confiscated, destroyed, or disappeared, to accompany this emptiness. The point was to reflect on Palestine's predicamentits lack of control over borders, waters, and skies-and to question the meaning of a museum, and the artifacts and collecting practices that supposedly define it, in the case of a people violently dispersed all over the globe and prevented from accessing their past and material present. In Art Is Not What You Think It Is, Claire Farago and Donald Preziosi demonstrate how the architecture of contemporary museums inspires active relationships between exhibitions and visitors, thereby provoking the potential that germinates in the built structure of the museum. ${ }^{9}$ Accordingly, when artists and curators are invited to converse with the spaces of museums rather than contexts of art-in-architecture, unexpected capacities may be set in motion which go beyond the ordinary encounters of exhibitions and spectatorship, works and visitors. Persekian and his team, conversant in global art theory and practice, were working within a genealogy of modern and contemporary art that conceptualized and theorized the museum space as an artwork and a statement in and of itself..$^{10}$

But having the museum empty for the official opening, which was scheduled to coincide with Nakba Day, did not go down well with the task force set up by Taawon to take charge of the museum project. ${ }^{11}$ Less interested in the language of conceptual art and the contemporary global artscape's often experimental approach to engaging with the political, and more concerned with the Palestinian Museum's role as a local cultural institution that speaks to the transterritorial Palestinian reality of displacement, solidarity networks, and grassroots initiatives, Taawon might have seen in the proposed opening a shift in the role of the Palestinian Museum from borderless center for Palestinian culture and heritage to what they perceived as an overly abstract and theorized project conversing more with the global art sphere than the local cultural scene. ${ }^{12}$ Being a grassroots organization, Taawon may also have been attuned to the fact that Palestinians, who lack sufficient access to their own artifacts but who value whatever material culture 
they are still in possession of as a means of historical narration, needed to see a museum that carried their name with objects in it, if only as a symbolic affirmation of their existence. Hence, even if the tradition of the empty museum (whether empty of audiences or artifacts) may have been an apt framework for highlighting the Palestinian condition in conceptual terms, in the Palestinian context, it takes on a different meaning.

When the Jewish Museum first opened without objects in Berlin in 1999 it was to highlight the eerily claustrophobic and uneven architecture of the zinc-clad building, which was meant to evoke feelings of fear, disorientation, and paranoia, even though the point of the museum was to celebrate Jewish contributions to the history of the city. ${ }^{13}$ Its initial emptiness corresponded to the message being conveyed. In the case of the Palestinians, history has put them in the absurd position of perpetually having to convince the rest of the world of their very existence. In response, scholars, artists, and filmmakers working in and on Palestine, interested in countering orientalist tropes representing the Palestinian as terrorist, victim, or romantic revolutionary, are slowly building a formidable archive of the historical fact and experience of ongoing dispossession and displacement, but also continued survival on the land. By recording and proactively reorganizing existing oral and visual testaments of surviving witnesses they are reassembling the story of the Palestinian struggle into a coherent and introspective counternarrative that rejects the central tenets of the media and public discourse on Islam, Arabs, and the Palestinians. Even if it is difficult to access, cultural heritage and specifically material culture is the site where this reclamation of narrative is fought for most fiercely.

Ironically, notwithstanding Taawon's misgivings about the curatorial conceptualization of emptiness, the museum ended up being empty on the day of its opening, thanks to a series of internal developments that culminated in the dismissal of Persekian, officially attributed to differences over "planning and management." ${ }^{14}$ Despite viewing the museum as incomplete, Taawon decided to move ahead with its opening to honor the promise they had made to open it on Nakba Day. ${ }^{15}$

It was difficult to ignore the ironies implicit in the opening of the empty museum in 2016 by the ever-unpopular Mahmoud Abbas, president of the PNA. This was especially true of mainstream Western media coverage. Headlines such as "Palestinian Museum Opens without Exhibits," "The Palestinian Museum Set to Open, Empty of Art," or, more provocatively, "Palestinian Museum Opening without Exhibits, but Creators Say That's No Big Deal" were predictably unkind. ${ }^{16}$ Cynically hinting at a people with neither the capacity nor the cultural history required to fill such an expensive and well-designed building, the media latched on to the fact that the Palestinian Museum was empty. Conveniently, these same media outlets almost entirely ignored the reality of Palestinian existence as a dispossessed people with histories, memories, and material cultures scattered all over the world or stolen by their colonizers through the cultural appropriation of music, books, art, and food, or the seizure of objects and especially archives. ${ }^{17}$ 
This reality, in addition to the lack of control over the movement necessary for the travel of art objects-normally central to a museum's practice-makes compiling, acquiring, and exhibiting works an almost impossible feat.

In artist Khaled Hourani's 2009 art project "Picasso in Palestine," Pablo Picasso's 1943 portrait of his lover Françoise Gilot, Buste de femme, was exhibited on the grounds of the International Art Academy of Palestine (IAAP) in Ramallah. The bringing of Picasso's Buste to Ramallah, a collaborative effort between the IAAP and the Van Abbe museum in the Netherlands that began at the Middle East Summit held at the museum in 2008, was nearly three years in the making. In Hourani's project, the process of bringing one of Picasso's most famous works to Palestine included wrestling with the thorny politics of Oslo, international protocols defining museum loan traditions that normally deal only with sovereign states, the bureaucratic measures implementing so-called peace agreements, and Israel's control over checkpoints, airports, and international insurance requirements. The point of the intriguing, if overly elaborate and expensive, project was to highlight just how difficult it would be to bring artworks to Palestine.

\section{ON THE POLITICAL ECONOMY OF MUSEUMS}

Only a few months after the tumultuous official opening of the Palestinian Museum without art objects in it, in a much-discussed public speech as part of the Young Artists of the Year Award (YAYA), hosted annually by the Abdel Mohsen Qattan Foundation, Omar Al-Qattan reproached the failure of the Palestinian cultural and artistic milieu in the era of Oslo to produce any meaningful dialogue or questions about the demise of the Palestinian national project. ${ }^{18}$ Having just returned from a trip to Gaza, Al-Qattan-also the director of the Al-Qattan Foundation, one of Ramallah's most prominent cultural institutions - seemed to be lashing out at the entire cultural scene. In fact, Al-Qattan expressed the discomfort that many, if not most members of the public, including writers, intellectuals, and artists, feel in the West Bank and Gaza about the extent to which cultural work and especially the visual arts have been able to engage with the collective Palestinian experience of oppression. In his words, he wanted to use the opportunity of the YAYA ceremony to address what he described as a "quickness, superficiality and general disengagement with historical and political subjects." ${ }^{\prime 9}$

Much has already been written about the debilitating and depoliticizing effects of the NGO-ization process created by international aid to the region-a process that has led to what is described by Palestinians as the collapse of the national liberation project. With globalization and transnational cultural markets becoming the norm in Palestine as elsewhere, artists and their institutions have not only been forced to readdress their role in the politics of the region and the transnational networks they need in order to survive, but also to present Palestine's plight and contributions to critical global conversations in the arts and activism more 
broadly. In Palestinian artist Khaled Hourani's words, "Artists started to reconsider the perception of arts, portraits, borders, artistic values, relations of artworks and exhibits, audience and arts dealers." ${ }^{20}$ Whether, as a generation of artists, they were in fact able to do so without compromising on the core values of cultural resistance and the role of contemporary art in it is, today, a central and uncomfortable discussion in Palestinian cultural circles.

Interestingly, on the day of the official inauguration of the museum in 2016, the building was empty of artifacts but not of objects such as the materials needed for the construction of the museum like shovels, barrels, and piles of cement. As some critics of the museum quipped, the fact that the museum was not emptied of its construction materials was a visual reminder of precisely how tied up it was in global capital circulation and real-estate development, a marker of post-Oslo Palestine par excellence, rather than a representation of the dispossessed and oppressed people it supposedly represented. ${ }^{21}$ This observation, which directly references the landscape dotted with cranes used to build the five-star hotels, restaurants, and upmarket housing that have come to define the "elite-driven production of space" in Ramallah in particular, prods us to think about the tensions between the provenance of the museum's capital and what it symbolizes. ${ }^{22}$

It is a fact that most of the investors in the Palestinian Museum were businessmen who made their money in the Arab Gulf. It is also believed that donations included in-kind contributions, revenue from which was channeled back into the construction, management, and development firms of some of the board's members. Adam Hanieh has shown how the internationalization of Gulf capital throughout the economies of the Middle East has been a central feature of regional capitalist development over the last two decades. ${ }^{23}$ Palestinian class formation since Oslo has gone hand in hand with the internationalization of capital, a process that sits at the heart of the economic doctrine of neoliberalism. Hanieh posits that Palestinian class formation cannot be understood solely through the prism of Palestine's subordination to Israel. Important businesses based in the Gulf have played a critical role in restructuring society in ways that make it highly reliant and dependent on transnational capital in order to survive. Along these lines, Sherene Seikaly provides a fascinating account of a dynamic class of Palestinian capitalist entrepreneurs involved in both local and regional trade, enabling us to historicize today's class of museum investors. ${ }^{24}$ Contemporary businesses are part of a longer genealogy of capital accumulation and investment in Palestine and the region at large. At the same time, they are only one component in a contingently linked cluster of people, technology, objects, and knowledge that circulate through the social and economic fields that museums inhabit. ${ }^{25}$ This raises a question: Even if the presence of construction material and workers visually symbolized Ramallah's role in the normalization of the occupation, and provoked the ambivalent feelings that some felt toward the opening of an empty museum, might it still be possible to separate the function of the Palestinian Museum as resistant praxis from the context of its provenance? 


\section{LANDSCAPE AND ARCHITECTURE}

Taking up a mere three thousand square meters of the forty thousand square meter plot on which it stands, the landscape in which the museum is set is as aesthetically and politically significant as the building and its artifacts. The visual and sensorial experience of standing in the foyer of the building is one of an affective encounter with the weight of history, the land, and continued presence on it. Indeed the topography of the land on which the museum is built and its terraced garden design was as significant to the conceptualization of the museum as the building itself. According to Lara Zureikat, the landscape architect, based in neighboring Amman, both understanding traditional practices of horticulture and working with the site's slopes and its existing plants were central to the Palestinian Museum's mission to respect the cultural and natural heritage of the landscape and its determination not to disrupt it yet again. ${ }^{26}$ This is in reference, and contrast, to the Israeli occupation's practice of intercepting and intervening in the harmony of the landscape for settlement construction, surveillance, and wall-building purposes, intrusions which sever Palestinians' access to cultivable land. ${ }^{27}$ Predictably, Zureikat, who is a Jordanian national, was prevented by Israel from visiting the site of the project. She and her team resorted to the use of satellite imagery and internet communication to finalize the project. This reveals how, from the beginning, the process of turning the museum into a material reality from an idea was imbricated with the museum's objective of building on the transterritorial reality of Palestinians by thinking imaginatively about modes of delivery.

The building is therefore physically and conceptually responsive to its landscape and built environment. In the words of Conor Sreenan, chief architect of the project, from the Dublin-based architecture firm Heneghan Peng, "It was the physical that introduced us to the geopolitical. We literally traced the existing topography and looked at the way that the landscape had been inhabited for 2000 plus years." ${ }^{28}$ The idea, he explained, was not to be defined by the occupation but rather to take back control of the landscape.

The hills of the West Bank, on which illegal Jewish settlements sit, visually embody what settler-colonialism entails and the consequences it has had. Some of these include moving communities into territories acquired in war-a Zionist practice that predates the establishment of the Israeli state-in addition to settler violence against local Palestinian communities and the imposition of new demographic realities on the ground that will not only threaten the form but the very possibility of a future Palestinian state. The planting on the grounds of the museum of groves of apricot, pomegranate, mulberry, cypress, olive, walnut and fig trees, lemons and oranges, herbs like zaatar, mint, and other plants that Israel has appropriated as part of a policy of erasing the memory and identity of Palestinian people, are a step towards reclaiming what has been taken away.

But standing inside the small museum and looking out of the floor-to-ceiling windows that adorn an entire wall that overlooks the hills and the Mediterranean 
Sea in the distance-which Palestinians are barred from reaching, thanks to Israeli-imposed restrictions on movement-the foundation on which Zionism stands is usurped, even mocked, if only momentarily. In other words, instead of directly confronting politics as such, the Palestinian Museum may in fact be aiming to create a platform from which to expand the meaning of the political to include not only critical thought and the collection and exhibition of dispersed art, but also to link the lived and built environments and peoples' relationships to each of these. With this in mind, even the sight of the unpopular Mahmoud Abbas cutting the ribbon on the opening day becomes more palatable.

THE ART INSTITUTION, THE STATE,

\section{AND DECOLONIZATION}

The PNA complained about the museum's apparent appropriation of what it saw as the state's role of cultural patronage, most visibly in the name the museum chose for itself: the Palestinian Museum. Despite this point of contention, Taawon felt the need to be courteous and to invite the president because in the end, as AlQattan explained, "we need to work with the existing bureaucratic structure and engage it, regardless of who is in power. We cannot function in isolation." ${ }^{29}$ Al Qattan's reasoning might sit uncomfortably with activists who see resisting colonial violence as a fundamentally confrontational act that requires tackling head-on the PNA's role as middleman of the occupation. Yet it is perhaps the only way in which to get a grand project of this kind off the ground in colonized Palestine today. The question that this reality begs is whether a museum of this kind was needed and whether Taawon would have done better to distribute its millions to the multitude of artists, writers, filmmakers, collectives, activists, and smaller-scale arts organizations that are working laboriously to collect and document Palestine's history and cultural heritage-a question I heard on numerous occasions in the field.

Rasha Salti and Kristine Khouri's Past Disquiet: Narratives and Ghosts from the International Art Exhibition for Palestine, 1978 revisits the making of the International Art Exhibition for Palestine, which opened in Beirut in the spring of 1978 and which comprised some two hundred works donated by artists in solidarity with Palestine from nearly thirty countries. Following the exhibit's inauguration in Beirut, and after parts of it had traveled to Japan, Norway, and then Iran some years later, the Israeli Army invaded Beirut in the summer of 1982 with the aim of flushing out the PLO. The building where the collection was stored was bombed, along with the offices of the PLO's Office of Unified Information where most of the archive of the exhibition would have been stored. Salti and Khouri's painstakingly curated exhibition traces the sheer challenge of locating the works, archives, stories, and memories today scattered all over the globe, but which were intended as a seed collection for a museum-in-exile until the moment it could "return" to a free Palestine. ${ }^{30}$ 
Palestinian artist Nasser Soumi has been working since the mid-199os to recover some of this lost cultural history by navigating the labyrinth of facts, urban legends, hints, clues, and social tensions that cluster around some of the disappeared paintings that featured in the show. When I recently asked him about his evident personal need to do so in the face of challenges he has faced from colleagues as well as the PNA that point to the impossibility of such collecting practices, he replied that Palestinians need some semblance of an art institution especially as their so-called state refuses to look for the story of resistance in places where it is not in control. ${ }^{31}$ For him, finding these works and knowing their story is a way for Palestinians to reclaim part of their lost archive.

These histories and artistic initiatives point to the importance of a site around which an oppressed people fighting for liberation may gather to (re)present their narratives, (re)negotiate their strategies of protest in the face of oppression, and reflect on their colonial pasts and presents by referencing objects and ideas that are accessible to them in physical or virtual form. From its plans to set up a virtual museum and online archival platforms to its construction of satellite museums (in Chile, the United States, United Kingdom, Jordan, and Lebanon) and its novel incorporation of landscape and topography into its programmatic definition and practices, the Palestinian Museum has committed itself in both concept and practice to ongoing anticolonial and decolonization processes. ${ }^{32}$ Its space is, then, equally a potential launch pad for interventions into, discourses on, and practices of decolonization, and specifically the "de-Westernizing" of knowledge production in a changing postcolonial world, by calling into question the principles that sustain the current dominant knowledge-production system, particularly in respect to art and museums. ${ }^{33}$

To appreciate what a significant institution the Palestinian Museum is, despite its precariousness, we need to revisit Palestinian historian Beshara Doumani's original conception of the project and the strategic plan he envisioned for it. Doumani was invited by Taawon in 2010 to submit a proposal for a museum to the organization's Palestinian Museum Task Force. To this day, the museum continues to use his original proposal as the blueprint for ongoing development of the project, even if it has been modified somewhat along the way. Doumani envisioned the museum as "postterritorial" in its need to encompass Palestinians who are scattered transterritorially and unable to access their homeland, and as "a mobilizing and interactive cultural project that can stitch together the fragmented Palestinian body politic by presenting a wide variety of narratives about the relationships of Palestinians to the land, to each other and to the wider world." ${ }^{34}$ His starting point wasn't the geographical locale of the West Bank and Gaza-even if the museum building would be situated near Ramallah, the purported capital of a future Palestinian state-but rather the dispersed and divided Palestinian population brought together through online technology. ${ }^{35}$ This population is composed of Gazans under siege, Jerusalemite Palestinians walled off from the rest of their people, 
Palestinians living in the West Bank who are intercepted, harassed, enclosed, and surrounded by a complex of Israeli checkpoints, as well the Palestinian citizens of Israel and all those living as refugees in neighboring Arab countries and as exiles in the rest of the world.

Doumani, like Soumi and others who witnessed or remember Israel's destruction of the Palestine Office of Unified Information, sees the importance of investing in the materiality of cultural practices, even if they will always be under existential threat and part and parcel of global capital circuits. In reality, the multimillion dollar investment project that is the museum can neither be defended nor easily rebuilt, should Israel decide to destroy it at any point. The museum, like other initiatives in Palestine, whether "state"- or civil society-led, is vulnerable to the closures, looting, and destruction to which all Palestinian cultural heritage has always been subject. This destruction is a possibility that financial investors have had to contend with. Sreenan describes the stoic perseverance of financial and other investors in the project during the dark days of the Gaza slaughter by Israel in 2014 as "possibly one of the most graceful acts of resistance one could ever witness." 36

Hence the question of the museum's role vis-à-vis the power structures it has to counter in the case of Israel and contend with in the case of the PNA was never about whether its construction would in and of itself be a compromise with the post-Oslo configuration of power. Rather, it was always about how it would negotiate with these power structures in order to position itself as a space of critique, resistance, and decoloniality in the convoluted colonial context of post-Oslo Palestine. As Doumani puts it, complicating the issue, "How this is done, of course, is of utmost importance." ${ }^{37}$

\section{IN THE COMPANY OF OTHER MUSEUMS}

The Palestinian Museum was first envisioned as a commemorative structure built around a single chronological narrative that begins in 1948. As it developed, it became clear to all those involved that in distancing itself from 1948 as the starting point of a chronological historical narrative, the museum would reject the standard Zionist line that the notion of a Palestinian people was constructed only after the establishment of the state of Israel in 1948. By beginning in the eighteenth century, it was agreed, the museum would better reflect the reality of the Palestinians as a dispersed people with urban, rural, and intellectual histories who were in existence well before Zionists began to arrive in Palestine and violently established their state. In this, the Palestinian Museum positions itself as a counternarrative not only to Israeli self-deception about the persecuted Jews of Europe having arrived to a land without a people, but also to the PNA's framing of the Palestinians as a people whose existence is articulated solely in opposition to Israel, as is evident in the museum projects in which it is involved. ${ }^{38}$ 
In both the Al-Birweh Park/Mahmoud Darwish Museum and the Yasser Arafat Museum in Ramallah (opened in 2014 and 2016 respectively), the PNA wrests control over narration from the people it governs in the name of figures who were dominant players (and narrators) in the Palestinian resistance movement and, in the case of Arafat, the Palestinian state formation project in the aftermath of the Oslo Accords. In other words, unlike the Palestinian Museum, the emphasis in the PNA's new multimillion-dollar museum projects is more on state power and state-building than on agency, peoplehood, and transterritoriality. More crucially, by focusing on Arafat and Darwish as the main characters in a story about the Palestinian struggle, the resistance is reified and commodified in ways that are both fathomable on the international stage and productive of nostalgia for the local public. What is insinuated through the aesthetics and narratives of the museums is that these figures are part of the struggle for independence from Israel that has supposedly been achieved with the signing of Oslo. They are stories from a glorious past, relics from a bygone era, what Svetlana Boym has termed a "dictatorship of nostalgia" that reigns at the supposed end of a conflict. ${ }^{39}$ Or alternatively, they are a chance to critique the past in order to imagine the future, as the director of the Yasser Arafat Museum suggested when I proposed my cynical reading to him. ${ }^{40}$ Ultimately, the differing temporal orientations of the Darwish and Arafat museums, dedicated to the past as a way of thinking about the future, on the one hand, and the Palestinian Museum, focused on the continuing reality of colonization, on the other, are reflected in the way one affectively experiences each of the museums.

Both the PNA's museum projects are exercises in formal and institutional design that evoke the state's legitimacy. By commissioning the late Jaafar Tuqan, one of the Arab world's most renowned modernist architects-known for his functionalism, simplicity, and minimalism, expressed in major institutional buildings such as mosques, government offices, banks, and schools throughout the Levant and the Arab Gulf over the past forty years-the PNA was asserting its role as the neutral state apparatus representing the public interest. In the case of the Mahmoud Darwish Museum, which is also the "temporary" mausoleum of Palestine's most loved poet, the small and darkened space that sits atop a mountain of stairs, and which holds most of Darwish's personal writings and belongings, could be an exhibition space visualizing state grandeur anywhere in the world. ${ }^{41}$ Unlike the Palestinian Museum, there is nothing inside save for the writings and book covers of Darwish's publications encased on the walls that tells visitors where they are. Formally, this could be a minimalist exhibition anywhere. Yet, like the Palestinian Museum, the Darwish Museum also deploys indigenous plants and the terraced gardening typical of the landscape to emphasize Palestinian claims over the land.

The role of museums in contributing to visualizing national identity is clearly identified in postcolonial literature. ${ }^{42}$ How political actors make use of these institutions as tools for the conduct of diplomacy or to claim a symbolic significance for the nation-state through the collections that are held within them are matters 
that relate to the political function of museums and the emotions they conjure up for the communities they represent. ${ }^{43}$ Yet the building of Palestine's museums, whether by civil society and private capital or by the state, cannot be fully understood outside of the tide of museum-building in the region. Focusing on national identity, societal development, and international understanding, museums in the Arab Gulf states of Qatar and the United Arab Emirates have taken it upon themselves in recent years to redraw Arab and Muslim identity on the global map as part of a larger process of diversifying their oil-based economies by investing in other areas. ${ }^{44}$ Though these efforts replicate the tools, modes, and ideas of Western museum construction and maintenance, Gulf states have been credited with taking the initiative to de-Westernize and decolonize Arab representations by delinking them from their original source: the Western museum and its historic relationship to the nation-state in the time of empire.

In the words of the decolonial theorist Walter Mignolo, writing about the Qatari Museum of Islamic Art in Doha, "What is happening is not merely an imitation of westernization, but an enactment of de-westernization in that western cultural standards are being appropriated and adapted to local or regional sensibilities, needs and visions. In the sphere of civilizations and museums, this is a significant departure." ${ }^{55}$ The suggestion that he and others have made is that prosperous and stable Arab capitals like Doha, Dubai, Abu Dhabi, and Muscat have the capability to redraw the global cultural map by redefining the Arab capital in a manner that is neither "Eurocentric nor Europhobic; neither retrograde nativist nor rootless cosmopolitan." 46

While there is something to these celebratory and hopeful takes on art infrastructure in the Gulf, what seems to be missing is an examination of how tied up these spaces are in regional geopolitics, economic diversification strategies, and military alliances with Western powers (evidenced not least by the location of military bases such as those of France in the United Arab Emirates or the United States in Qatar), even if they are seemingly de-Westernizing art discourses and collecting practices by rerouting the direction of travel and sales of each. Decolonial claims do not seem to factor in the corporate power that often shapes the conversations that take place in and about museums, even if these museums-especially as in the case of the Gulf museums - are able to reverse art market trends by paying more for artworks than traditional Western art patrons, such as the British Museum, are able to today. I would argue that this process by itself is not proof that a decolonial epistemic shift is occurring, in the absence of evidence of the production of one's own knowledge on one's own terms, outside of market constraints.

My reference to other museums in Palestine and the Arab region more generally is not intended to suggest that the Palestinian Museum is somehow more resistant or more worthy as a museum "for the people by the people." Instead, my point concerns the need to start a conversation about the content and form of museums in the region that do not fit the emerging Gulf museum format of massive, 
powerful symbols of capital defined by aesthetically minimalist, white-cube styles that are a means to assert global relevance and centrality. I want to ask how smaller "postcolonial" museums, like the Palestinian Museum, that are not commissioned as part of a larger national strategic plan, intervene in the space of "decoloniality" that the Gulf is ironically now celebrated as spearheading.

It is no coincidence that the financial patrons of the Palestinian Museum have made their money in the Gulf. It is also possible that future links between the Palestinian Museum and Gulf museums will be solidified through staff training and other professional and infrastructural development that will be needed as the Palestinian Museum grows. What these links will signify, and how they will shape the direction that the museum will take, warrant continuing scrutiny and discussion.

The Palestinian Museum's mission of wresting back the narratives, material culture, and memories that have been so crudely taken from the Palestinian people is a reminder of an integral element of decolonization. If we think of decolonization in the realm of museum curation as entailing not simply a decentering of the art market and the flows of art sales, as suggested in the decolonial claims of Mignolo and others, but also a forestalling of the violence of amnesia and narrative erasure that accompanies colonialism in Palestine, a new emancipatory definition of the term may be enunciated. ${ }^{47}$ For all its faults and the criticism it might incur in the future, the Palestinian Museum is ultimately striving to seize control over its destiny not only from its oppressor Israel but also from hegemonic understandings and practices of statehood, peoplehood, space, time, and architecture. For that, it should be celebrated not only as a triumphant moment in the cultural history of the Palestinian people, but also as a genuinely emancipatory moment in the grand project of epistemic decolonization, for Palestinians and for other colonized peoples everywhere.

\section{NOTES}

This article is reprinted with the permission of the journal Radical Philosophy, where it first appeared in December 2018.

1. Joseph Massad, "The 'Post-colonial' Colony: Time, Space, and Bodies in Palestine/Israel," The Pre-occupation of Postcolonial Studies, eds. Fawzia Afzal-Khan and Kalpana Seshadri-Crooks (Durham, NC: Duke University Press 2000), 311-46.

2. See Eilean Hooper-Greenhill, Museums and the Interpretation of Culture (London and New York: Routledge, 2000)

3. See the Museum's website on this concept: palmuseum.org/about/the-building-2.

4. On the "postcolonial museum," see Alessandra De Angelis, Celeste Ianniciello, Mariangela Orabona and Iain Chambers, eds., The Postcolonial Museum: The Arts of Memory and the Pressures of History (Abingdon: Routledge, 2016); and Sonja Mejcher-Atassi and John Pedro Schwartz, eds., Archives, Museums and Collecting Practices in the Modern Arab World (Abingdon: Routledge, 2016), both of which have paved the way for a reconceptualization of objects and collections as "processes or practices and not just things." See also Elizabeth Edwards, Chris Gosden and Ruth B. Phillips, eds., Sensible Objects: Colonialism, Museums and Material Culture (Oxford: Berg, 2006). 
5. See for instance Pamela Erskine-Loftus, Victoria Penziner Hightower, and Mariam Ibrahim Al-Mulla, eds., Representing the Nation: Heritage, Museums, National Narratives and Identity in the Arab Gulf States (Abingdon: Routledge, 2016); Hayfa Matar, "Museums as Signifiers in the Gulf," in Cities, Museums and Soft Power, eds. Gail Dexter Lord and Ngaire Blankenberg, 87-98 (Washington, DC: AAM Press, 2015). Peggy Levitt, Artifacts and Allegiances: How Museums Put the Nation and the World on Display (Oakland: University of California Press, 2015) offers a dynamic approach to understanding museums' roles as sites of cosmopolitanism in an increasingly transnationalized and global world.

6. The A.M. Qattan Foundation is an independent, not-for-profit developmental organization working in the fields of culture and education, with a particular focus on children, teachers, and young artists.

7. Taawon mission statement, accessed March 13, 2018, taawon.org.

8. "Jack Persekian, Director of Palestinian Museum, Resigns," Artforum, December 11, 2015 , artforum.com/news/jack-persekian-director-of-palestinian-museum-resigns-56674.

9. Donald Preziosi and Claire Farago, Art Is Not What You Think It Is (Oxford: Wiley-Blackwell, 2012).

10. See for instance Steven Conn, Do Museums Still Need Objects? (Philadelphia: University of Pennsylvania Press, 2010); Edwards, Gosden, and Phillips, Sensible Objects.

11. Nakba is the Arabic word for catastrophe and Nakba Day (May 15) was officially designated by Yasser Arafat in 1998 as the official day of mourning to coincide with Israel's official celebration of its establishment in 1948.

12. For Al-Qattan's criticisms of the global art world's approach to cultural production, which he sees as "far too restricted, abstract, filled with jargon, falsely academic," see Shany Littman, "Even Empty, the New Palestinian Museum Is Making History," Haaretz, May 26, 2016, http://haaretz.com /israel-news/culture/.premium-1.721510.

13. Esra Akcan, "Apology and Triumph: Memory Transference, Erasure, and a Rereading of the Berlin Jewish Museum," New German Critique 37, no. 2 (2010): 153-79.

14. "Jack Persekian," Artforum; James Glanz and Rami Nazzal, "Palestinian Museum Prepares to Open, Minus Exhibitions," The New York Times, May 16, 2016, nytimes.com/2016/05/17/world/midd leeast/palestinian-museum-birzeit-west-bank.html.

15. Zina Jardaneh, chair of the board of the Palestinian Museum, interview with author, December $17,2017$.

16. "New Palestinian Museum Opens without Exhibits," BBC News, May 18, 2016, http://bbc .com/news/world-middle-east-36322756; William Booth, "Palestinian Museum Opening without Exhibits, but Creators Say That's No Big Deal," Washington Post, May 18, 2016; 'Palestinian History Museum Opens without Any Exhibits," Associated Press, May 19, 2016, ynetnews.com /articles/o,7340,L-4805141,oo.html.

17. See for instance Hannah Mermelstein, “Overdue Books: Returning Palestine's 'Abandoned Property' of 1948," Jerusalem Quarterly 47 (Autumn 2011): 199-228; Gish Amit, “Ownerless Objects? The Story of the Books Palestinians Left behind in 1948," Jerusalem Quarterly 33 (Winter 2008): 7-20; Sarah Irving, "Endangered Archives' Program Opens Up Priceless Palestinian Heritage," Electronic Intifada, May 13, 2014, electronicintifada.net/blogs/sarah-irving/endangered-archives-programopens-pricless-palestinian-heritage.

18. The Young Artists of the Year Award, named after the late artist Hassan Hourani, is one of the most important events in the visual arts calendar of Palestine and has been organized on a biannual basis by the A.M. Qattan Foundation since 2000. For some who were present at the YAYA ceremony, Al Qattan's words seemed harsh generalizations that overlooked the real achievement of getting Palestine onto the world cultural map. For others, Al-Qattan seemed to be pushing his audience to think honestly and critically about the global political economy of arts production that Palestinian artists, like artists elsewhere, have had to negotiate with, often at the expense of effacing local historical 
and ongoing processes of resistance. See Tarek Hamdan, "Omar Al-Qattan: Bakae'ya Muta'akhira ... Walakin" [Omar Al-Qattan: A belated jeremiad ... or not], Al Akhbar, October 16, 2016. Al-Qattan offered a detailed response to the Al-Akhbar piece, which he saw as wrongfully representing his statement: "Omar Al-Qattan: (Cultural) Palestine Will Not Die," A.M. Qattan Foundation, December 6, 2016, qattanfoundation.org/en/qattan/media/news/omar-al-qattan-cultural-palestine-will-not-die.

19. Interview with author, December 20, 2017.

20. Khaled Hourani, "Globalisation Questions and Contemporary Art's Answers: Art in Palestine," in Globalisation and Contemporary Art, ed. Jonathan Harris, 297-306 (Oxford: Wiley-Blackwell, 2009), 301.

21. Lara Khalidi, an independent curator from Palestine, takes up this point in her paper "The Museum before the Museum," presented at Harvard Graduate School Quincy School of Design, November 6, 2017.

22. Nasser Abourahme, "The Bantustan Sublime: Reframing the Colonial in Ramallah," City 13, no. 4 (2009): 499-509.

23. Adam Hanieh, Capitalism and Class in the Gulf Arab States (New York: Palgrave Macmillan, 2011). See also chapter 1 of this volume.

24. Sherene Seikaly, Men of Capital: Scarcity and Economy in Mandate Palestine (Stanford, CA: Stanford University Press, 2016).

25. Levitt, Artifacts and Allegiances, 8.

26. Lara Zureikat, phone interview with author, November 23, 2017.

27. Eyal Weizman, Hollow Land: Israel's Architecture of Occupation (London: Verso, 2012), 120.

28. Conor Sreenan, Skype interview with author, December 5, 2017.

29. Omar Al-Kattan, phone interview with author, December 17, 2017.

30. For the curators' description of the project and its content, see Kristine Khouri and Rasha Salti, "Past Disquiet: From Research to Exhibition," Artl@s Bulletin 5, no. 1 (2016), article 8.

31. This conversation was part of an exchange I had with Soumi and others on a panel titled "Before the Museum," for which I was invited to be the discussant, as part of the symposium Shifting Ground: The Underground Is Not the Past, held at the Khalil Sakakini Cultural Centre as part of the Tamawuj chapter of the thirteenth Sharjah Biennial, held in Ramallah August 10-14, 2017.

32. For instance, the Museum is currently running two projects, "Palestinian Journeys" and the "Palestinian Museum Digital Archive," that constitute a large part of the open-access digital platform that will collect, organize, and archive Palestinian history in Palestine. See palmuseum.org/projects/e -platforms-1.

33. For an earlier take on the changing scope and content of the decolonization process, see Jan Nederveen Pieterse and Bhikhu Parekh, eds., The Decolonisation of Imagination: Culture, Knowledge and Power (London: Zed Books, 1995).

34. Ursula Biemman, "A Post-Territorial Museum: Interview with Beshara Doumani," Arte East Quarterly, Spring 2010, arteeast.org/quarterly/a-post-territorial-museum/?issues_season=spring\& issues_year=2010.

35. I am not suggesting that this approach is the Palestinian Museum's alone. Since the late 1990 s many museums have invested in an online presence and incorporated a wide range of web-based formats into their programs and exhibits in order to enable access by a global public.

36. Conor Sreenan, Skype interview with author, December 5, 2017.

37. Beshara Doumani, informal discussion with author, Providence, RI, December 4, 2017.

38. I want to stress here that this counternarrative is extremely important and necessary insofar as it responds to Israel's military and Zionist discursive narrative, which attempts to erase the Palestinian people. However, there is a need to go beyond the defensive. As Doumani puts it, "How can Palestinians take control of and shape their own narratives, but not in a defensive mechanical way that simply responds to how they are represented by others?" Biemman, "A Post-Territorial Museum."

39. Svetlana Boym, The Future of Nostalgia (New York: Basic Books, 2002), 354. 
40. Mohammad Halayka, interview with author, Ramallah, May 23, 2018.

41. Both the mausoleums of Yasser Arafat and Mahmoud Darwish are generally regarded as temporary in anticipation of the day when they can be transplanted to Jerusalem, the occupied capital city that Palestinians, like Israelis, perceive as theirs.

42. Rodney Harrison and Lotte Hughes, "Heritage, Colonialism and Postcolonialism," in Understanding the Politics of Heritage, ed. Rodney Harrison, 243-67 (Manchester: Manchester University Press, 2010).

43. Clive Gray, The Politics of Museums (Basingstoke: Palgrave Macmillan, 2015); Melissa Nisbett, "New Perspectives on Instrumentalism: An Empirical Study of Cultural Diplomacy," International Journal of Cultural Policy 19, no. 5 (2013): 557-75. It is also interesting to take note of a roundtable discussion conducted between Jack Persekian, the former director of the Palestinian Museum, curator Lara Khalidi, and artist Yazan Khalil, on the nature of a museum in the context of a state that does not exist. Khalidi questions whether Palestinians are able to creatively take advantage of their nonstate status to interrogate other forms of political existence that the museum could experiment with. The one point that Persekian goes back to is that the museum is a civil society project that does not intend to represent the state but rather, works in parallel to it. See Welfare Association and the Palestinian Museum, Muqaddima fi al Mathaf al Falastinya (Ramallah: Welfare Association and the Palestinian Museum, 2014), 10-14.

44. Suzi Mirgani, "Introduction: Art and Cultural Production in the GCC," Journal of Arabian Studies, 7, no. 1 (2017): 1-11.

45. Walter Mignolo, "Enacting the Archives, Decentering the Muses: The Museum of Islamic Art in Doha and the Asian Civilisations Museum in Singapore," Ibraaz 006 (2013): 11-12, ibraaz.org/usr /library/documents/main/enacting-the-archives.pdf.

46. Hamid Dabashi, "Rethinking the Arab Capital through Art," Al Jazeera, April 10, 2017, aljazeera.com/indepth/opinion/2017/04/rethinking-arab-capital-art-170409105111270.html; Hamid Dabashi, "What Are the Saudis Afraid Of?" Al Jazeera, December 17, 2017, www.aljazeera.com/indepth /opinion/saudis-afraid-171217082544270.html.

47. Mignolo's understanding of decoloniality (as opposed to decolonization) is closely linked to the process of "delinking" as he expounds it in "Delinking: The Rhetoric of Modernity, the Logic of Coloniality and the Grammar of De-coloniality," Cultural Studies 21, no. 2-3 (2007): 449-514, 453. Here he refers to a process that leads to decolonial epistemic shifts that in turn propose alternative universalities or what he terms "pluri-versality" as a universal project.

\section{BIBLIOGRAPHY}

Abourahme, Nasser. “The Bantustan Sublime: Reframing the Colonial in Ramallah.” City 13, no. 4 (2009): 499-509.

Akcan, Esra. "Apology and Triumph: Memory Transference, Erasure, and a Rereading of the Berlin Jewish Museum." New German Critique 37, no. 2 (2010): 153-79

Amit, Gish. "Ownerless Objects? The Story of the Books Palestinians Left behind in 1948." Jerusalem Quarterly 33 (Winter 2008): 7-20.

Biemman, Ursula. "A Post-Territorial Museum: Interview with Beshara Doumani." ArteEast Quarterly, Spring 2010. arteeast.org/quarterly/a-post-territorial-museum/?issues _season $=$ spring\&issues_year $=2010$.

Boym, Svetlana. The Future of Nostalgia. New York: Basic Books, 2002.

Conn, Steven. Do Museums Still Need Objects? Philadelphia: University of Pennsylvania Press, 2010. 
De Angelis, Alessandra, Celeste Ianniciello, Mariangela Orabona, and Ian Chambers, eds. The Postcolonial Museum: The Arts of Memory and the Pressures of History. Abingdon: Routledge, 2016.

Edwards, Elizabeth, Chris Gosden, and Ruth B. Phillips, eds., Sensible Objects: Colonialism, Museums and Material Culture. Oxford: Berg, 2006.

Erskine-Loftus, Pamela, Victoria Penziner Hightower, and Mariam Ibrahim Al-Mulla, eds. Representing the Nation: Heritage, Museums, National Narratives and Identity in the Arab Gulf States. Abingdon: Routledge, 2016.

Gray, Clive. The Politics of Museums. Basingstoke: Palgrave Macmillan, 2015.

Hanieh, Adam. Capitalism and Class in the Gulf Arab States. New York: Palgrave Macmillan, 2011.

. “The Oslo Illusion.” Jacobin, April 2013. jacobinmag.com/2013/04/the-oslo-illusion.

Harrison, Rodney, and Lotte Hughes. "Heritage, Colonialism and Postcolonialism." In Understanding the Politics of Heritage, edited by Rodney Harrison, 243-67. Manchester: Manchester University Press, 2010.

Hooper-Greenhill, Eilean. Museums and the Interpretation of Culture. London: Routledge, 2000.

Hourani, Khaled. "Globalisation Questions and Contemporary Art's Answers: Art in Palestine." In Globalisation and Contemporary Art, edited by Jonathan Harris, 297-303. Oxford: Wiley-Blackwell. 2009.

Khalidi, Lara. "The Museum before the Museum." Paper presented at Harvard Graduate School Quincy School of Design, November 6, 2017.

Khouri, Kristine, and Rasha Salti. "Past Disquiet: From Research to Exhibition." Artl@s Bulletin 5, no. 1 (2016), article 8.

Levitt, Peggy. Artifacts and Allegiances: How Museums Put the Nation and the World on Display. Oakland: University of California Press, 2015.

Massad, Joseph. “The 'Post-colonial' Colony: Time, Space, and Bodies in Palestine/Israel.” In The Pre-occupation of Postcolonial Studies, edited by Fawzia Afzal-Khan and Kalpana Seshadri-Crooks, 311-46. Durham, NC: Duke University Press 2000.

Matar, Hayfa. "Museums as Signifiers in the Gulf." In Cities, Museums and Soft Power, edited by Gail Dexter Lord and Ngaire Blankenberg, 87-98. Washington, DC: American Alliance of Museums Press, 2015.

Mejcher-Atassi, Sonja, and John Pedro Schwartz, eds. Archives, Museums and Collecting Practices in the Modern Arab World. Abingdon: Routledge, 2016.

Mermelstein, Hannah. “Overdue Books: Returning Palestine's 'Abandoned Property' of 1948." Jerusalem Quarterly 47 (Autumn 2011): 199-228.

Mignolo, Walter. "Delinking: The Rhetoric of Modernity, the Logic of Coloniality and the Grammar of De-coloniality." Cultural Studies 21, no. 2-3 (2007): 449-514.

—. "Enacting the Archives, Decentering the Muses: The Museum of Islamic Art in Doha and the Asian Civilisations Museum in Singapore." Ibraaz oo6 (November 2013). ibraaz.org/usr/library/documents/main/enacting-the-archives.pdf.

Mirgani, Suzi. "Introduction: Art and Cultural Production in the GCC." Journal of Arabian Studies 7, no. 1 (2017): 1-11.

Nederveen Pieterse, Jan, and Bhikhu Parekh, eds. The Decolonisation of Imagination: Culture, Knowledge and Power. London: Zed Books, 1995. 
Nisbett, Melissa. "New Perspectives on Instrumentalism: An Empirical Study of Cultural Diplomacy." International Journal of Cultural Policy 19, no. 5 (2013): 557-75.

Preziosi, Donald, and Claire Farago. Art Is Not What You Think It Is. Oxford: Wiley-Blackwell, 2012.

Seikaly, Sherene. Men of Capital: Scarcity and Economy in Mandate Palestine. Stanford, CA: Stanford University Press, 2016.

Welfare Association and the Palestinian Museum, Muqaddima fi al Mathaf al Falastinya. Ramallah: Welfare Association and the Palestinian Museum, 2014.

Weizman, Eyal. Hollow Land: Israel's Architecture of Occupation. London: Verso, 2012. 